\title{
Shoot Growth and Development of Alamo Switchgrass as Influenced by Mowing and Fertilization
}

\author{
M.R. HAFERKAMP AND T.D. COPELAND
}

\begin{abstract}
The response of shoot development and forage yield of a 2-year old 'Alamo' switchgrass stand to mowing and fertilization was evaluated to provide information needed for effective management of this variety. Mowing to a $20-\mathrm{cm}$ stubble height in mid-spring removed only a few apical meristems and had little impact on shoot development. Late spring and early summer mowing were done when apical meristems of primary compound shoots were elevated to near the $20-\mathrm{cm}$ cutting height in May and over $20 \mathrm{~cm}$ in June. Secondary nonrooted shoot and aerial shoot numbers were increased and plant vigor, measured by spring growth in 1980, was decreased slightly the following spring. Mowing in mid-summer removed apical meristems from essentially all primary compound shoots and many secondary compound shoots. Regrowth was slight during the remainder of the summer, but the number of secondary and tertiary nonrooted shoots and aerial shoots increased. The number of proaxis buds decreased, and plant vigor was severely decreased the following spring. Mowing twice including early fall, removed apical meristems from secondary compound shoots and some primary and secondary nonrooted shoots. Numbers of secondary, tertiary, and quarternary nonrooted shoots increased, but proaxis bud numbers were reduced. Plant vigor was very low the following spring, possibly due to exposure of mowed plants to cold winter temperatures. Fertilization increased the rate of development of compound and nonrooted shoots, the number of secondary and compound shoots in spring, the number of proaxis buds in fall and the weight of primary and secondary compound shoots. Fertilized stands mowed during summer and early fall were more productive than all other mowed stands. Fertilized plants mowed in mid-summer were vigorous and productive the following spring. However, fertilization did not overcome the loss of vigor caused by fall mowing.
\end{abstract}

Alamo switchgrass (Panicum virgatum L.) was released by the United States Department of Agriculture, Soil Conservation Service and the Texas Agricultural Experiment Station in 1979 as a commercial variety for use in pasture and range seedings (Anonymous 1979). The variety has proven superior to other switchgrass varieties for forage production in central and southern Texas. However, little information is available concerning the effects of clipping and fertilization on forage yield and shoot development of Alamo switchgrass.

Defoliation of grasses may increase tillering and reduce the high

\footnotetext{
The authors were assistant professor and graduate research assistant, Texas Agricultural Experiment Station (Dept. of Range Science), Texas A\&M University, College Station 77843. Present addresses are Eastern Oregon Agricultural Research Center, Squaw Butte Station, Burns 97720; and Big Lake, Texas 79720.

The authors gratefully acknowledge the USDA. Soil Conservation Service, Plant Materials Center, Knox City, Texas, for providing seed; Dr. J.W. Stuth, Dr. D. Briske, and Dr. E.C. Holt for their helpful suggestions and reviews; and Mr. Don

Shelton for assistance in the statistical analysis.

Approved for publication by the Director, Texas Agricultural Experiment Station, as Tech. Article No. TA-18546.

Manuscript accepted December 8, 1983.
}

proportion of senescent leaves and shoots (Hyder 1974). Frequent defoliation, or clipping to a short stubble, however, can cause stand reduction and reduce forage production with many switchgrass varieties (Branson 1953, Neiland and Curtis 1956, Dwyer et al. 1963, Dwyer and Elder 1964, Beaty and Powell 1976).

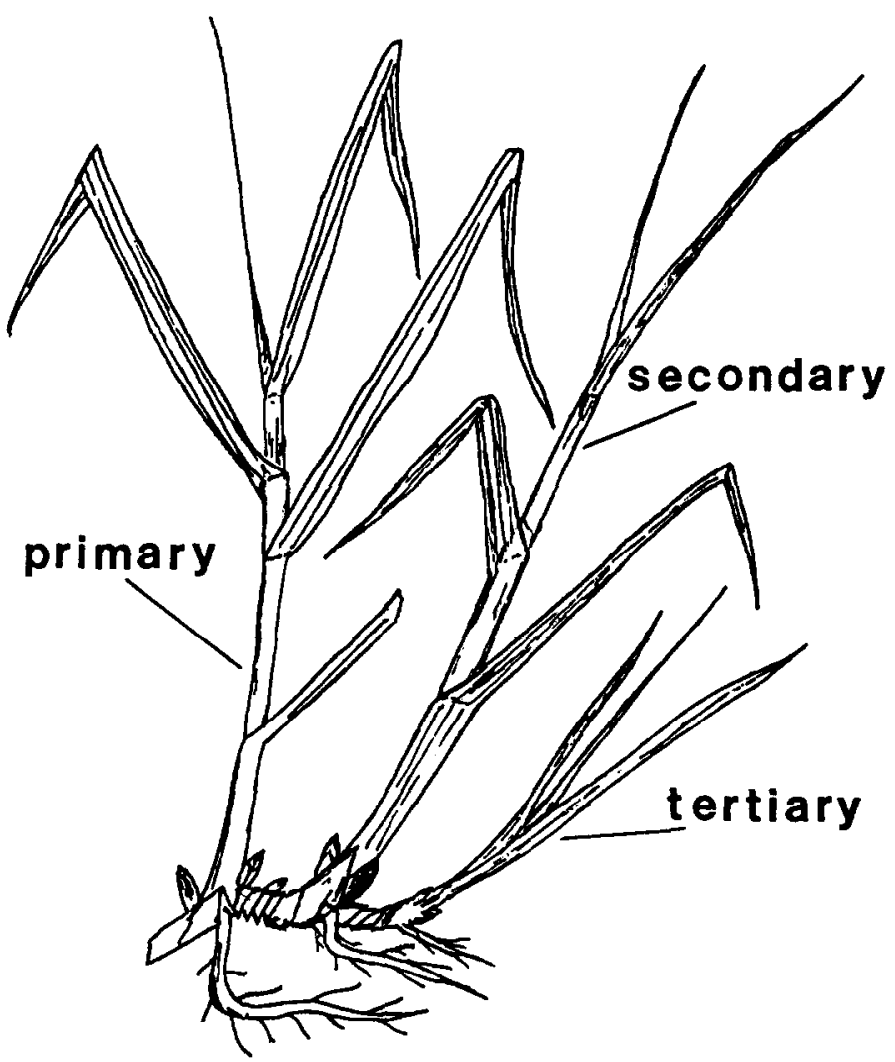

Fig. 1. Example of a shoot system of Alamo switchgrass with primary, secondary, and tertiary compound shoots.

Switchgrass elevates shoot apicies early and produces a high ratio of reproductive to vegetative shoots, making it sensitive to clipping (Branson 1953). Switchgrass produces one crop of tillers in the spring and early removal can seriously reduce herbage production (Hyder 1974). According to Beaty and Powell (1976), switchgrass will tolerate a single defoliation almost anytime with no year to year reduction in vegetative vigor; however, 2 or more clippings per year reduce plant and crown survival. Dwyer and Elder (1964) found that moderate grazing of switchgrass reduced animal gains in August and September. Reduction in gain occurred because plants were producing inflorescences and leaves 

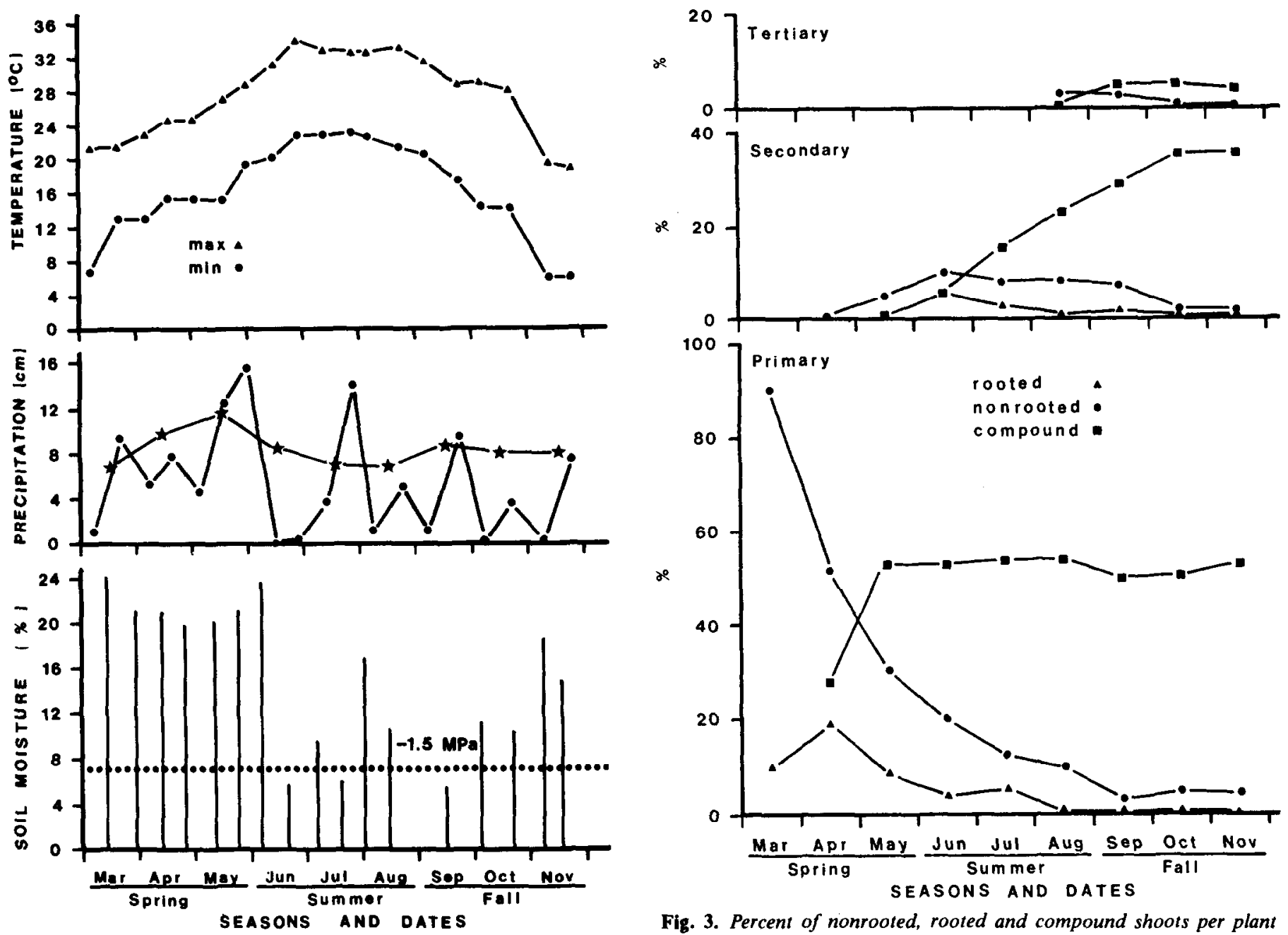

Fig. 3. Percent of nonrooted, rooted and compound shoots per plant within primary, secondary or tertiary shoot categories for untreated Alamo switchgrass plants growing near College Station, Texas. Values are the means of 3 replicates.

Fig. 2. Soil moisture $(\%) 0-30 \mathrm{~cm}$ depth, precipitation (cm) annual $(\bullet)$ and 99 vear average $(\star)$. and air temperature $\left({ }^{\circ} \mathrm{C}\right.$ ) maximum ( $\Delta$ and minimum ( $\bullet$ occurring near College Station, Texas, during MarchNovember 1979.

were dying or dead. When switchgrass plants were grazed at a heavier rate ( $74 \%$ utilization), plants were maintained in an immature state, but shoot vigor was reduced by the close defoliation. Time of defoliation also influences regrowth of switchgrass. Sims et al. (1971) found that defoliating switchgrass plants prior to June 26 induced rhizomes to produce aerial shoots and inflorescences before the end of the growing season. Plants defoliated after June 26 produced small shoots that quickly went dormant. Holt (unpublished data) reported that shoot apicies of several accessions of switchgrass growing near College Station, Texas, were evaluated above a $20-\mathrm{cm}$ grazing and cutting height by late spring. If shoot apicies were not removed with early spring defoliation a marked decrease in forage production resulted.

Effective management of switchgrass is tied closely to shoot growth (stem elongation) of plants. The objective of this study was to evaluate the effect of fertilization and mowing on growth, shoot density and shoot growth of Alamo switchgrass.

\section{Materials and Methods}

The investigation was conducted on a 2-year-old stand of Alamo switchgrass, located on the Texas A\&M Range Research Area near College Station. The soil, a Lufkin fine sandy loam, in the taxonomic class of Fine, montmorillonitic, thermic Vertic Albaqualfs with a hard restrictive layer of clay $20-30 \mathrm{~cm}$ below the soil

surface occurs within the Post Oak Savannah resource area (Gould 1975). Mean annual rainfall at the site is $100 \mathrm{~cm}$ with a peak in May.

Main plots $5 \times 32 \mathrm{~m}$ in size were either untreated; fertilized in early spring (March) with 45-45-45 kg/ ha of N, $\mathrm{P}_{2} \mathrm{O}_{5}$ and $\mathrm{K}_{2} \mathrm{O}$; or mowed to a $20-\mathrm{cm}$ stubble height in mid-spring (April 15), late spring (May 15), early summer (June 15), and mid-summer (July 15). The main plots were arranged in a randomized block design with 3 replications. One-half of each fertilized plot was mowed in mid-summer (July 15) and one-half of all mowed plots were mowed again in early fall (September 15).

Beginning in early spring (March) and continuing through late fall (November), 5 plants were excavated from each plot at 2 to- 4 week intervals. Whole plants from mowed plots were excavated prior to or just after mowing and soil was removed from root systems before storing. Collected plants were frozen or oven-dried at $70^{\circ} \mathrm{C}$. Frozen samples were stored at $0^{\circ} \mathrm{C}$ until examined in the laboratory, and oven-dried samples were stored at room temperature.

Shoot numbers and weights were determined for each plant. Shopts and axillary buds were sorted by a system similar to those used by Stubbendieck and Burzlaff (1970), Dewald and Louthan (1979), and Nieland and Curtis (1956). Shoots with no roots were classified as nonrooted. Those with at least one root but without basal (proaxis) bud formation or secondary shoots were classified as rooted shoots; and shoots with secondary shoots or proaxis buds were classified as compound shoots. In early growth, proaxis 
buds and rhizomes, were difficult to distinguish and were grouped together as proaxis buds. Axillary buds with green leaf elongation and located on elevated nodes were classified as aerial shoots. Shoots were further classified as primary (arising from buds formed the preceding year); secondary (arising from buds of primary compound shoots); or tertiary (arising from secondary compound shoots) (Fig. 1). The expanded leaves were counted and height of apical meristems was measured on only the unmowedfertilized and untreated plants. All shoots were dried for 48 hours at $60^{\circ} \mathrm{C}$ and weighed.

Standing crop ( $\mathrm{kg} / \mathrm{ha}$ ) above a 20 -cm stubble height was determined by clipping prior to mowing in April, May, June, July, or September 1979. These samples represented the amount of forage harvested with the mowing treatments. Plants within each of 5 randomly placed $0.5-\mathrm{m}^{2}$ sample quadrats per replication were counted and clipped to a height of $20 \mathrm{~cm}$, oven-dried at $60^{\circ} \mathrm{C}$ for at least 48 hours and weighed. Standing crop to ground level was also calculated by multiplying average number of plants per $\mathrm{m}^{2}$ by average weight per excavated plant determined by summation of the weight of shoots in each category in the shoot development phase. On March 5, 1980, stands were burned to about a $5-\mathrm{cm}$ stubble height to remove the standing dead forage from plots. Axillary buds had begun to swell, but no growth had occurred at this time. Thus, the burn was not considered detrimental to the switchgrass plants. Plants were allowed to grow, and standing crop was sampled by clipping plants to ground level on May 15, 1980. Plants within 4 randomly placed $0.5-\mathrm{m}^{2}$ areas per replication were clipped and dried at $60^{\circ} \mathrm{C}$ for 48 hours and weighed. Data were used to determine effects of fertilization and mowing treatments upon plant growth in spring following treatment.

Soil temperatures at depths of $7.5,15$, and $30 \mathrm{~cm}$, air temperatures, and precipitation were measured continuously during the study. Soil moisture was determined gravimetrically on samples collected from the $0-7.5 \mathrm{~cm}, 7.5-15 \mathrm{~cm}, 15-30 \mathrm{~cm}$, and $30-45 \mathrm{~cm}$ depths. These soil samples were taken within the untreated plot of each replication at approximately 2 -week intervals.

Analysis of variance was conducted to compare treatment effects on shoot type, shoot weights, and plant weights across time. Treatment means were separated and significant differences were calculated at the $10 \%$ level.

\section{Results and Discussion}

\section{Growth and Development}

Growth of untreated Alamo switchgrass plants was monitored during a year with above-average total rainfall but with a drier than usual early summer and early fall (Fig. 2). Plants began growth in early spring with development of primary nonrooted shoots from proaxis buds formed the previous growing season. Adventitious roots began to form when shoots were in the three-to four-leaf stage. With development of roots, percent of primary nonrooted shoots decreased from $90 \%$ in early March to $3 \%$ by September (Fig. 3). Primary rooted shoots increased to $20 \%$ of the shoot component in mid-spring but decreased as proaxis buds formed and primary compound shoots developed. Percentage of primary compound shoots rapidly increased to $50 \%$ of the shoot component and remained stable for the remainder of the growing season. Primary compound shoots at tained the six-leaf stage by early July, when flowering was also first observed. Anthesis occurred in late July and early August.

Secondary shoots developed in mid-spring from proaxis buds of primary compound shoots (Fig. 3). Percentages of secondary shoots in all categories were less than percentages of primary shoots. Secondary shoots formed about $25 \%$ of the shoot complex by early summer. Nonrooted shoots decreased from $10 \%$ of the shoot complex in early summer to $2 \%$ in mid-fall. Secondary rooted shoots were transient in nature, in that the percentage increased with root initiation in late spring, but decreased with increased development of proaxis buds in summer. Secondary compound shoots increased from $0 \%$ during mid-spring to $35 \%$ by late fall. A third generation of shoots began to form from proaxis buds in late summer. By early fall tertiary shoots comprised about $5 \%$ of the shoot complex and remained at this level during the remainder of the season. The nonrooted shoot component was never greater than $3 \%$, and tertiary compound shoots reached a maximum of $5 \%$ in early fall. Compound shoots comprised over $90 \%$ of the shoot complex by the end of the growing season (Fig. 3), and proaxis buds located at the base of compound shoots numbered 40 per plant by late fall (Table 1).

\section{Mid-spring Mowed}

Mowing in mid-spring had little impact on the shoot complex, but the total weight of primary compound shoots was reduced during fall (Table 2). Mowing removed less than $150 \mathrm{~kg} /$ ha forage (Table 3) and only a few apical meristems, but the treatment reduced plant vigor (1980 spring regrowth) by $30 \%$ (Table 4). April mowed plants regrew relatively slowly during the period from late-spring to mid-summer 1979 (Fig. 4).

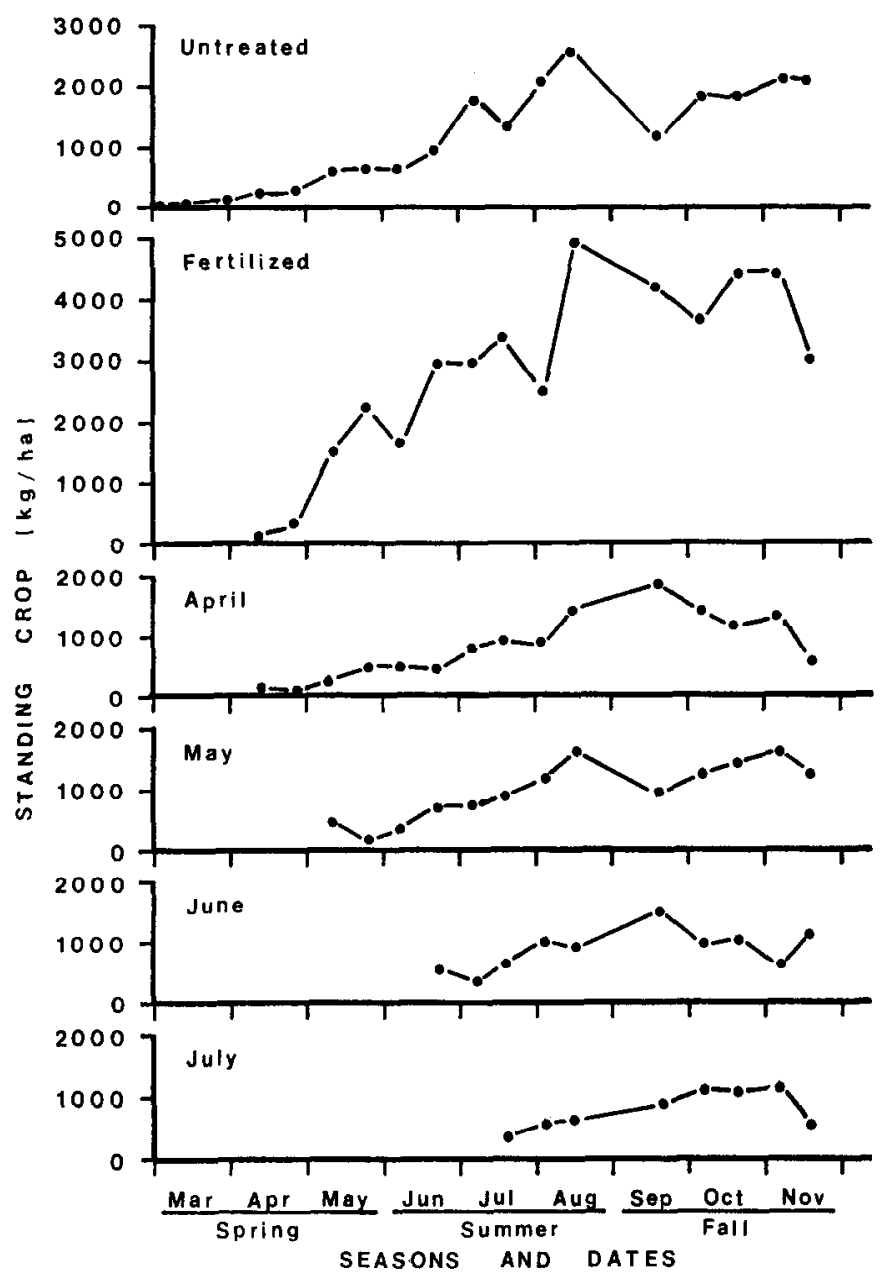

Fig. 4. Standing crop ( $\mathrm{kg} / \mathrm{ha}$ ) of Alamo switchgrass growing near College Station, Texas, during 1979. Estimates equaled the average weight of excavated plants $X$ average number of plants per hectare.

Several factors may have been active in effectively reducing regrowth of April mowed plants in 1979. Brownseed paspalum (Paspalum plicatulum Michx.) plants were actively growing in April defoliated plots and may have competed for moisture. Beaty and Powell (1976) reported that clipping switchgrass plots in spring and summer allowed invasion of weeds into switchgrass stands in Georgia. Harvests later in the year reduced invasion. Temperatures in mid-spring (Fig. 2) were also below the $32^{\circ} \mathrm{C}$ day $/ 26^{\circ} \mathrm{C}$ night temperatures reported optimum for switchgrass 
Table 1. The average number of proaxis buds per plant for untreated, fertilized or mowed treatments of Alamo switchgrass growing near College Station, Texas, during 1979. Values are the means of three replicates.

\begin{tabular}{|c|c|c|c|c|c|c|c|c|c|}
\hline \multirow[b]{4}{*}{ Treatment } & \multicolumn{9}{|c|}{ Season and date of harvest } \\
\hline & \multicolumn{3}{|c|}{ Spring } & \multicolumn{3}{|c|}{ Summer } & \multicolumn{3}{|c|}{ Fall } \\
\hline & \multicolumn{2}{|c|}{ April } & \multirow{2}{*}{$\begin{array}{c}\text { May } \\
24\end{array}$} & \multirow{2}{*}{$\begin{array}{c}\text { June } \\
20\end{array}$} & \multirow{2}{*}{$\begin{array}{c}\text { July } \\
19 \\
\end{array}$} & \multirow{2}{*}{$\frac{\text { August }}{16}$} & \multirow{2}{*}{$\frac{\text { Sept. }}{20}$} & \multirow{2}{*}{ Oct. } & \multirow{2}{*}{$\frac{\text { Nov. }}{17}$} \\
\hline & 12 & 26 & & & & & & & \\
\hline $\begin{array}{l}\text { Unmowed } \\
\text { Unfertilized } \\
\text { Fertilized }^{2}\end{array}$ & $\begin{array}{l}5 \mathbf{a}^{1} \\
7 \mathbf{a}^{-}\end{array}$ & $\begin{array}{c}10 a b \\
17 a\end{array}$ & $\begin{array}{l}15 b \\
33 a\end{array}$ & $\begin{array}{l}27 a b \\
31 a\end{array}$ & $\begin{array}{l}24 a \\
28 a\end{array}$ & $\begin{array}{l}48 a \\
37 b\end{array}$ & $\begin{array}{l}29 b c \\
41 a\end{array}$ & $\begin{array}{l}34 a b \\
42 a\end{array}$ & $\begin{array}{l}40 \mathrm{ab} \\
52 \mathrm{a}\end{array}$ \\
\hline $\begin{array}{l}\text { Mowed once } \\
\text { April } \\
\text { May } \\
\text { June } \\
\text { July } \\
\text { Fertilized } 2 / \text { July }\end{array}$ & $2 a$ & $7 b$ & $\begin{array}{c}14 b c \\
8 c\end{array}$ & $\begin{array}{l}15 c \\
18 c \\
20 b c\end{array}$ & $\begin{array}{c}20 \mathrm{ab} \\
12 \mathrm{bc} \\
7 \mathrm{c} \\
20 \mathrm{ab} \\
27 \mathrm{a}\end{array}$ & $\begin{array}{r}26 c \\
27 c \\
23 c \\
5 d \\
3 d\end{array}$ & $\begin{array}{c}25 \mathrm{~cd} \\
25 \mathrm{~cd} \\
39 \mathrm{ab} \\
16 \mathrm{de} \\
8 \mathrm{e}\end{array}$ & $\begin{array}{l}38 \mathrm{ab} \\
33 \mathrm{ab} \\
36 \mathrm{ab} \\
37 \mathrm{ab} \\
30 \mathrm{~b}\end{array}$ & $\begin{array}{l}32 b c \\
29 b c \\
42 a b \\
25 c \\
30 b c\end{array}$ \\
\hline $\begin{array}{l}\text { Mowed twice } \\
\text { April/September } \\
\text { May/September } \\
\text { June/September } \\
\text { July/September } \\
\text { Fertilized } 2 \text { July/September }\end{array}$ & & & & & & & & $\begin{array}{l}4 c \\
4 c \\
5 c \\
4 c \\
5 c\end{array}$ & $\begin{array}{l}3 d \\
4 d \\
6 d \\
3 d \\
6 d\end{array}$ \\
\hline
\end{tabular}

1 Means within a column followed by the same letter are not significantly different at the 0.90 level according to Duncan's multiple range test.

${ }^{2}$ Fertilized March 1979 with 45-45-45 kg/ha N, $\mathrm{P}_{2} \mathrm{O}_{5}, \mathrm{~K}_{2} \mathrm{O}$.

Table 2. Average weight (g) of primary compound shoots per plant for untreated, fertilized or mowed treatments of Alamo switchgrass growing near College Station, Texas, during 1979. Each value is the mean of three replicates.

\begin{tabular}{|c|c|c|c|c|c|c|c|c|c|}
\hline \multirow[b]{4}{*}{ Treatment } & \multicolumn{9}{|c|}{ Season and date of harvest } \\
\hline & \multicolumn{3}{|c|}{ Spring } & \multicolumn{3}{|c|}{ Summer } & \multicolumn{3}{|c|}{ Fall } \\
\hline & \multicolumn{2}{|c|}{ April } & \multirow{2}{*}{$\frac{\text { May }}{24}$} & \multirow{2}{*}{$\begin{array}{c}\text { June } \\
20 \\
\end{array}$} & \multirow{2}{*}{$\frac{\text { July }}{19}$} & \multirow{2}{*}{$\frac{\text { August }}{16}$} & \multirow{2}{*}{$\frac{\text { Sept. }}{20}$} & \multirow{2}{*}{$\frac{\text { Oct. }}{20}$} & \multirow{2}{*}{$\frac{\text { Nov. }}{17}$} \\
\hline & 12 & 26 & & & & & & & \\
\hline $\begin{array}{l}\text { Unmowed } \\
\text { Unfertilized } \\
\text { Fertilized }^{2}\end{array}$ & $\begin{array}{l}2 a^{\prime} \\
4 a\end{array}$ & $\begin{array}{r}4 a \\
14 a\end{array}$ & $\begin{array}{l}11 b \\
35 a\end{array}$ & $\begin{array}{l}17 \mathrm{~b} \\
54 \mathrm{a}\end{array}$ & $\begin{array}{l}21 b \\
46 a\end{array}$ & $\begin{array}{l}42 b \\
73 a\end{array}$ & $\begin{array}{l}19 b c \\
60 a\end{array}$ & $\begin{array}{l}23 b \\
56 a\end{array}$ & $\begin{array}{l}27 b \\
56 a\end{array}$ \\
\hline $\begin{array}{l}\text { Mowed once } \\
\text { April } \\
\text { May } \\
\text { June } \\
\text { July } \\
\text { Fertilized } 2 / \text { July }\end{array}$ & $2 a$ & $9 a$ & $\begin{array}{l}8 b c \\
3 c\end{array}$ & $\begin{array}{l}8 b \\
9 b \\
9 b\end{array}$ & $\begin{array}{c}15 c \\
9 c \\
9 c \\
6 c \\
12 b c\end{array}$ & $\begin{array}{l}20 \mathrm{bc} \\
16 \mathrm{~cd} \\
9 \mathrm{e} \\
7 \mathrm{e} \\
12 \mathrm{de}\end{array}$ & $\begin{array}{l}22 \mathrm{~b} \\
15 \mathrm{bcd} \\
10 \mathrm{de} \\
6 \mathrm{e} \\
13 \mathrm{bcd}\end{array}$ & $\begin{array}{l}13 \mathrm{~cd} \\
17 \mathrm{bc} \\
8 \mathrm{de} \\
6 \mathrm{de} \\
8 \mathrm{de}\end{array}$ & $\begin{array}{l}14 \mathrm{c} \\
11 \mathrm{bcd} \\
9 \mathrm{~cd} \\
6 \mathrm{~cd} \\
13 \mathrm{~cd}\end{array}$ \\
\hline $\begin{array}{l}\text { Mowed twice } \\
\text { April/September } \\
\text { May/September } \\
\text { June/September } \\
\text { July/September } \\
\text { Fertilized } 2 \text { /July/September }\end{array}$ & & & & & & & & $\begin{array}{l}5 e \\
4 e \\
6 \mathrm{de} \\
3 \mathrm{e} \\
5 \mathrm{e}\end{array}$ & $\begin{array}{l}5 \mathrm{~cd} \\
5 \mathrm{~cd} \\
4 \mathrm{~cd} \\
2 \mathrm{~d} \\
8 \mathrm{~cd}\end{array}$ \\
\hline
\end{tabular}

'Means within a column followed by the same letter are not significantly different at the 0.90 level according to Duncan's multiple range test.

${ }^{2}$ Fertilized March 1979 with $45-45-45 \mathrm{~kg} /$ ha $\mathrm{N}, \mathrm{P}_{2} \mathrm{O}_{5}, \mathrm{~K}_{2} \mathrm{O}$.

Table 3. Standing crop (kg/ha) of fertilized and mowed stands of Alamo switchgrass growing near College Station, Texas, clipped to a $20 \mathrm{~cm}$ stubble height during 1979 . Values are the means of three replicates.

\begin{tabular}{lccc}
\hline & \multicolumn{2}{c}{ Harvests } & \\
\cline { 2 - 3 } Treatments & First & Second & Total \\
\hline April/September & 133 & 1608 & 1741 \\
May/September & 526 & 1623 & 2149 \\
June/September & 1294 & 1523 & 2817 \\
July/September & 1152 & 602 & 1754 \\
Fertilized $/$ July/September & 4015 & 1122 & 5137 \\
\hline
\end{tabular}

'Fertilized March 1979 with 45-45-45 kg/ha N, $\mathrm{P}_{2} \mathrm{O}_{5}, \mathrm{~K}_{2} \mathrm{O}$. growth by Balasko and Smith (1971). The regrowth potential of Alamo switchgrass plants, determined by the number of proaxis buds associated with compound shoots, was also lowest in April and increased as the growing season progressed (Table 1). Thus, mowing in April could possibly have delayed the allocation of carbon compounds for the formation of new proaxis buds. The cause for reduced plant vigor during spring 1980 is not clear because plants should have had adequate time for herbage production and carbohydrate storage.

\section{Late-spring and Early-summer Mowed}

Plants mowed in late spring and early summer responded similarly. Secondary nonrooted shoots increased in number following 
Table 4. Standing crop ( $\mathrm{kg} / \mathrm{ha}$ ) of untreated, fertilized or mowed Alamo switchgrass stands harvested to ground level on May 15, 1980 near College Station, Texas. Table values represent spring regrowth following uniform burn in March 1980 and are the means of three replicates.

\begin{tabular}{lc}
\hline \hline Treatment & Standing Crop \\
\hline Unmowed & $3022 \mathrm{~b} /$ \\
Unfertilized & $4790 \mathrm{a}$ \\
Fertilized ${ }^{2}$ & \\
Mowed once & $2118 \mathrm{~cd}$ \\
April & $2278 \mathrm{bc}$ \\
May & $2482 \mathrm{bc}$ \\
June & $1374 \mathrm{de}$ \\
July & $2654 \mathrm{bc}$ \\
Fertilized $2 /$ July & \\
Mowed twice & $1216 \mathrm{e}$ \\
April/September & $1068 \mathrm{e}$ \\
May/September & $1272 \mathrm{e}$ \\
June/September & $642 \mathrm{e}$ \\
July/September & $1310 \mathrm{e}$ \\
Fertilized $2 /$ July/September & \\
\hline
\end{tabular}

INumbers followed by the by the same letter are not significantly different at the 0.90 level according to Duncan's multiple range test.

2Fertilized March 1979 with 45-45-45 kg/ha N, $\mathrm{P}_{2} \mathrm{O}_{5}, \mathrm{~K}_{2} \mathrm{O}$.

mowing of primary compound shoots (Table 5). Aerial shoots also developed from axillary buds (Table 6). The number of proaxis buds decreased slightly during the summer as new shoots were formed (Table 1). Possibly, defoliation reduced apical dominance during the summer when proaxis buds were adequately developed to produce new shoots. Apical meristems of primary compound shoots were elevated to near $20 \mathrm{~cm}$ in May and over $20 \mathrm{~cm}$ in June. Weights of secondary nonrooted and aerial shoots increased three and six fold, respectively, compared to those of untreated plants, and weights of compound shoots were reduced $60 \%$ by mowing (Table 2). A single defoliation in early summer yielded about 1,200 $\mathrm{kg} / \mathrm{ha}$ forage, twice the amount harvested in late spring (Table 3). Plant vigor in stands defoliated in May and June decreased 18 to $25 \%$ during spring 1980 relative to untreated plants (Table 4).
Table 6. The average number of aerial shoots per plant for untreated, fertlized or mowed treatments of Alamo switchgrass growing near College Station, Texas during fall 1979. Values represent the means of three replicates.

\begin{tabular}{|c|c|c|}
\hline \multirow[b]{2}{*}{ Treatment } & \multicolumn{2}{|c|}{ Date } \\
\hline & October 20 & November 17 \\
\hline $\begin{array}{l}\text { Unmowed } \\
\text { Unfertilized } \\
\text { Fertilized }^{3}\end{array}$ & $\begin{array}{l}0 d^{\prime} \\
0 d^{\prime}\end{array}$ & $\begin{array}{l}0 \mathrm{~d} \\
0 \mathrm{~d}\end{array}$ \\
\hline $\begin{array}{l}\text { Mowed once } \\
\text { April } \\
\text { May } \\
\text { June } \\
\text { July } \\
\text { Fertilized }{ }^{3} / \text { July }\end{array}$ & $\begin{array}{l}1 d \\
2 c d \\
5 a b c \\
5 a b c \\
8 a b\end{array}$ & $\begin{array}{l}T^{2} \\
3 \mathrm{~cd} \\
6 \mathrm{bc} \\
4 \mathrm{bc} \\
10 \mathrm{a}\end{array}$ \\
\hline $\begin{array}{l}\text { Mowed twice } \\
\text { April/September } \\
\text { May/September } \\
\text { June/September } \\
\text { July/September } \\
\text { Fertilized } 3 \text { /July/September }\end{array}$ & $\begin{array}{l}7 \mathrm{ab} \\
7 \mathrm{ab} \\
9 \mathrm{a} \\
5 \mathrm{bc} \\
5 \mathrm{bc}\end{array}$ & $\begin{array}{l}6 \mathrm{bc} \\
7 \mathrm{~b} \\
5 \mathrm{bc} \\
4 \mathrm{bc} \\
4 \mathrm{bc}\end{array}$ \\
\hline
\end{tabular}

Means within a column followed by the same letter are not significantly different at the 0.90 level according to Duncan's multiple range test.

${ }^{2}$ Average 0.5 or less.

${ }^{3}$ Fertilized March 1979 with $45-45-45 \mathrm{~kg} / \mathrm{ha} \mathrm{N}, \mathrm{P}_{2} \mathrm{O}_{5} \mathrm{~K}_{2} \mathrm{O}$

\section{Mid-summer Mowed}

Mowing in mid-summer increased the number of secondary and tertiary nonrooted shoots and aerial shoots (Table 5, 6 and 7). Proaxis bud numbers decreased and remained low through late summer and then increased in fall (Table 1). Forage yields were similar to those of early summer defoliated plants (Table 3), but this treatment caused a severe decline in plant vigor the following spring (Table 4). We can only speculate that growing conditions during latc summer and fall were not adequate for growth and subsequent carbohydrate replenishment (Fig. 2). Apical meristems were removed from essentially all of the primary compound shoots and many of the secondary compound shoots, and regrowth was slight during the remainder of the summer (Table 3).

\section{Mowed Twice}

A similar pattern of shoot development occurred in stands mowed twice, with the second mowing

Table 5. Average number of secondary nonrooted shoots per plant for untreated, fertilized or mowed treatments of Alamo switchgrass growing near College Station, Texas during 1979 . Values represent the means of three replicates.

\begin{tabular}{|c|c|c|c|c|c|c|c|c|}
\hline \multirow[b]{4}{*}{ Treatment } & \multicolumn{8}{|c|}{ Season and date of harvest } \\
\hline & \multicolumn{2}{|c|}{ Spring } & \multicolumn{3}{|c|}{ Summer } & \multicolumn{3}{|c|}{ Fall } \\
\hline & April & May & June & July & August & Sept. & Oct. & Nov. \\
\hline & 26 & 24 & 20 & 19 & 16 & 20 & 20 & 17 \\
\hline $\begin{array}{l}\text { Unmowed } \\
\text { Unfertilized } \\
\text { Fertilized }{ }^{2}\end{array}$ & $\begin{array}{l}0.4 \mathrm{~b}^{\prime} \\
2.6 \mathrm{a}\end{array}$ & $\begin{array}{l}1.2 \mathrm{~b} \\
2.8 \mathrm{~b}\end{array}$ & $\begin{array}{l}2.0 \mathrm{~b} \\
2.6 \mathrm{~b}\end{array}$ & $\begin{array}{l}2.0 \mathrm{c} \\
2.3 \mathrm{c}\end{array}$ & $\begin{array}{l}2.0 \mathrm{~d} \\
0.9 \mathrm{~d}\end{array}$ & $\begin{array}{l}1.6 \mathrm{~cd} \\
1.0 \mathrm{~d}\end{array}$ & $\begin{array}{l}0.3 \mathrm{e} \\
0.6 \mathrm{e}\end{array}$ & $\begin{array}{l}0.6 \mathrm{de} \\
0.0 \mathrm{e}\end{array}$ \\
\hline $\begin{array}{l}\text { Mowed once } \\
\text { April } \\
\text { May } \\
\text { June } \\
\text { July } \\
\text { Fertilized } 2 / \text { July }\end{array}$ & $0.1 b$ & $\begin{array}{l}3.0 \mathrm{~b} \\
7.0 \mathrm{a}\end{array}$ & $\begin{array}{r}2.4 \mathrm{~b} \\
14.0 \mathrm{a} \\
3.6 \mathrm{~b}\end{array}$ & $\begin{array}{c}2.8 \mathrm{c} \\
7.4 \mathrm{~b} \\
11.6 \mathrm{a} \\
5.7 \mathrm{bc} \\
3.0 \mathrm{c}\end{array}$ & $\begin{array}{l}1.5 \mathrm{~d} \\
4.7 \mathrm{~cd} \\
7.4 \mathrm{bc} \\
9.5 \mathrm{~b} \\
18.3 \mathrm{a}\end{array}$ & $\begin{array}{l}0.9 \mathrm{~d} \\
2.2 \mathrm{bcd} \\
5.7 \mathrm{abc} \\
6.2 \mathrm{ab} \\
9.4 \mathrm{a}\end{array}$ & $\begin{array}{l}0.0 \mathrm{e} \\
1.1 \mathrm{e} \\
2.7 \mathrm{~d} \\
2.7 \mathrm{~d} \\
3.5 \mathrm{bcd}\end{array}$ & $\begin{array}{l}0.2 \mathrm{e} \\
0.8 \mathrm{e} \\
2.0 \mathrm{de} \\
2.5 \mathrm{cde} \\
4.8 \mathrm{a}\end{array}$ \\
\hline $\begin{array}{l}\text { Mowed twice } \\
\text { April/September } \\
\text { May/September } \\
\text { June/September } \\
\text { July/September } \\
\text { Fertilized2/July/September }\end{array}$ & & & & & & & $\begin{array}{l}5.3 \mathrm{a} \\
4.6 \mathrm{abc} \\
3.4 \mathrm{~cd} \\
3.2 \mathrm{~cd} \\
4.9 \mathrm{ab} \\
\end{array}$ & $\begin{array}{l}3.9 \mathrm{ab} \\
3.5 \mathrm{abc} \\
1.8 \mathrm{cdc} \\
1.4 \mathrm{de} \\
3.8 \mathrm{abc} \\
\end{array}$ \\
\hline
\end{tabular}

IMeans within a column followed by the same letter are not significantly different at the 0.90 level according to Duncan's multiple range test.

${ }^{2}$ Fertilized March 1979 with $45-45-45 \mathrm{~kg} / \mathrm{ha} \mathrm{N}, \mathrm{P}_{2} \mathrm{O}_{5}, \mathrm{~K}_{2} \mathrm{O}$. 
Table 7. Average number of tertiary nonrooted shoots and quarternary nonrooted shoots per plant for untreated, fertilized or mowed treatments of Alamo switchgrass growing near College Station, Texas, during fall 1979. Values represent the means of three replicates.

\begin{tabular}{|c|c|c|c|c|}
\hline \multirow[b]{2}{*}{ Treatment } & \multicolumn{2}{|c|}{ Tertiary } & \multicolumn{2}{|c|}{ Quarternary } \\
\hline & October 20 & November 17 & October 20 & November 17 \\
\hline $\begin{array}{l}\text { Unmowed } \\
\text { Unfertilized } \\
\text { Fertilized }^{2}\end{array}$ & $\begin{array}{l}0 . \mid b^{1} \\
0.2 b\end{array}$ & $\begin{array}{l}0.0 \mathrm{f} \\
0.2 \mathrm{f}\end{array}$ & $\begin{array}{l}0.0 \mathrm{c} \\
0.0 \mathrm{c}\end{array}$ & $\begin{array}{l}0.0 \mathrm{a} \\
0.0 \mathrm{a}\end{array}$ \\
\hline $\begin{array}{l}\text { Mowed once } \\
\text { April } \\
\text { May } \\
\text { June } \\
\text { July } \\
\text { Fertilized } 2 / \text { July }\end{array}$ & $\begin{array}{l}0.0 \mathrm{~b} \\
0.0 \mathrm{~b} \\
0.3 \mathrm{~b} \\
1.0 \mathrm{~b} \\
2.8 \mathrm{~b}\end{array}$ & $\begin{array}{l}0.2 \mathrm{f} \\
0.2 \mathrm{f} \\
0.2 \mathrm{f} \\
1.3 \mathrm{ef} \\
3.0 \mathrm{def}\end{array}$ & $\begin{array}{l}0.0 c \\
0.0 c \\
0.0 c \\
0.0 c \\
0.1 b c\end{array}$ & $\begin{array}{l}0.0 \mathrm{a} \\
0.0 \mathrm{a} \\
0.0 \mathrm{a} \\
0.0 \mathrm{a} \\
0.0 \mathrm{a}\end{array}$ \\
\hline $\begin{array}{l}\text { Mowed twice } \\
\text { April/September } \\
\text { May/September } \\
\text { June/September } \\
\text { July/September } \\
\text { Fertilized² }\end{array}$ & $\begin{array}{r}11.1 \mathrm{a} \\
10.6 \mathrm{a} \\
8.5 \mathrm{a} \\
8.9 \mathrm{a} \\
8.6 \mathrm{a}\end{array}$ & $\begin{array}{c}8.0 \mathrm{~b} \\
12.3 \mathrm{a} \\
4.0 \mathrm{~cd} \\
5.4 \mathrm{~cd} \\
7.0 \mathrm{bc}\end{array}$ & $\begin{array}{l}1.0 \mathrm{ab} \\
0.5 \mathrm{abc} \\
0.3 \mathrm{bc} \\
1.3 \mathrm{a} \\
1.0 \mathrm{ab}\end{array}$ & $\begin{array}{l}0.2 \mathrm{a} \\
0.6 \mathrm{a} \\
0.3 \mathrm{a} \\
1.0 \mathrm{a} \\
0.3 \mathrm{a}\end{array}$ \\
\hline
\end{tabular}

I Means within a column followed by the same letter are not significantly different at the 0.90 level according to Duncan's multiple range test.

${ }^{2}$ Fertilized March 1979 with 45-45-45 kg/ha N, $\mathrm{P}_{2} \mathrm{O}_{5}, \mathrm{~K}_{2} \mathrm{O}$.

occurring in early fall. Apical meristems were removed from most secondary compound shoots and some primary and secondary nonrooted shoots. Numbers of secondary, tertiary and quarternary nonrooted shoots increased as they developed from the proaxis buds (Tables 5 and 7). Nonrooted shoots became dormant after frost in late fall and resumed growth the following spring. Weights of the nonrooted shoot component increased (data not shown), but weights of rooted and compound shoot components decreased (Table 2). Total forage yields ranged from 1,700 to 2,800 $\mathrm{kg}$ / ha with maximum yields produced by an initial harvest in late spring and early summer (Table 3). Vigor of these plants, based on plant weight in spring 1980 , was low relative to untreated plants or those mowed once in spring or early summer (Table 4).

Exposure of fall mowed plants to winter temperatures during 1979-80 (Fig. 2) that were .8 to $3^{\circ} \mathrm{C}$ below the long term average in November, December, February, March, and April may have reduced plant growth in spring 1980 . Fall mowed big sacaton (Sporobolus wrightii Munro) plants also grew slowly the next spring (Haferkamp 1982). Switchgrass plants mowed in fall produced many small nonrooted shoots that became dormant and resumed growth the following spring (Tables 5 and 7), and these shoots may have been damaged by cold temperatures, thus reducing spring growth of fall mowed plants. Beaty and Powell (1976) also reported that 2 clippings per year on switchgrass reduced plant survival as well as the number of shoots per plant, but a single clipping was not detrimental.

\section{Fertilization}

Fertilization in early spring increased rate of development of compound shoots from nonrooted and rooted shoots (data not shown). Numbers of secondary nonrooted shoots and secondary compound shoots (data not shown) were significantly higher in fertilized plants in April and a trend toward a greater number of proaxis buds was apparent for the fall (Tables 5 and 1). Fertilization did not influence numbers of primary compound shoots (data not shown), but increased weights of primary and secondary compound shoots (Table 2). Fertilized plots were also the most productive during the growing season and the spring following treatment (Tables 3 and 4). Increases in forage production from fertilization have been reported for switchgrass by other researchers (Warnes and Newell 1969, Balasko and Smith 1971).

\section{Fertilization and Mowing}

Plants fertilized in spring and mowed in mid-summer yielded the most forage (Table 3 ), and these plants were almost as vigorous as untreated plants the following spring (Table 4). Mowing removed apical meristems from both primary and secondary compound shoots. Fertilization apparently overcame the detrimental effects of mid-summer mowing. Fertilized plants contained significantly more secondary nonrooted shoots (Table 5) and aerial shoots (Table 6) and produced $500 \mathrm{~kg} / \mathrm{ha}$ more regrowth than nonfertilized plants by fall (Table 3 ). However, numbers of proaxis buds were similar (Table 1). The enhanced growth response during spring of 1980 may have been due to a residual fertilizer effect.

\section{Management Implications}

These data indicate that deferment or light defoliation of Alamo switchgrass in early spring would allow development of compound shoots and an increased potential for plant regrowth in areas climatically similar to the Post Oak Savannah of Texas. Severe defoliation during this period could reduce vigor of plants by allowing invasion of weeds and subsequently reduce the growth rate of new shoots. Excessive defoliation in the fall could decrease the potential for early spring growth by reducing numbers of proaxis buds and by allowing damage due to low temperature.

Fertilization with a mid-summer defoliation was the most productive in terms of amount of forage harvested and plant vigor. The forage quality during mid-summer, however, would be lower than in spring or early summer.

\section{Literature Cited}

Anonymous. 1979. Alamo switchgrass. Tex. Agr. Exp. Sta. L-1774.

Balasko, J.A., and D. Smith. 1971. Influence of temperature and nitrogen fertilization on the growth and composition of switchgrass (Panicum virgatum L.) and timothy (Phleum pratense L.) at anthesis. Agron. J. 63:853-857.

Beaty, E.R., and J.D. Powell. 1976. Response of switchgrass (Panicum virgatum L.) to clipping frequency. J. Range Manage. 29:132-135.

Branson, F.A. 1953. Two new factors affecting resistance to grazing. J. Range Manage. 6:165-171.

Dewald, C.L., and V.H. Louthan. 1979. Sequential development in eastern gama grass. J. Range Manage. 32:147-151.

Dwyer, D.D., and W.C. Elder. 1964. Grazing comparison of Woodward sand bluestem and Caddo switchgrass in Oklahoma. Okla. Agr. Exp. Sta. B-628.

Dwyer, D.D., W.C. Elder, and G. Singh. 1963. Effects of height and frequency of clipping on pure stands of range grasses in north central Oklahoma. Oklahoma Agr. Exp. Sta. B-614.

Gould, F.W. 1975. Texas plants: A checklist and ecological summary. Texas Agr. Exp. Sta. MP-585/Revised. 
Haferkamp, M.R. 1982. Defoliation impacts on quantity and quality of forage harvested from big sacaton (Sporobolus wrightii Munro). J. Range Manage. 35:26-31.

Hyder, D.N. 1974. Morphogensis and management of perennial grasses in the United States. In: K.W. Kreitlow and R.H. Hart (eds.). Plant morphogensis as the basis for scientific management of the range resources. USDA Misc. Pub. 1271.
Neiland, B.M., and J.T. Curtis. 1956. Differential responses to clipping of six prairie grasses in Wisconsin. Ecol. 37:355-356.

Sims, P.L., L.J. Ayuko, and D.N. Hyder. 1971. Developmental morphology of switchgrass and sideoats grama. J. Range Manage. 29:357-360. Stubbendieck, J., and D.F. Burzlaff. 1970. Effects of temperature and day length on axillary bud and tiller development in blue grama. J. Range Manage. 23:63-66.

Warnes, D.D., and L.C. Newell. 1969. Establishment and yield responses of warm-season grass strains to fertilization. J. Range Manage. 22:235240 . 